\title{
Is a Change in the Renminbi Exchange Rate in China's Interest? ${ }^{1}$ \\ Barry Eichengreen \\ University of California, Berkeley
}

\section{Introduction}

For much of 2003 and 2004, China's currency peg was the number-one international economic and financial issue in the United States. Senator Charles Schumer (D-NY) introduced legislation to impose an across-the-board tariff of 27.5 per cent on imports from China to penalize the country for manipulating its currency. President Bush, Secretary Snow and Chairman Greenspan all weighed in on the need for a more flexible renminbi exchange rate.

Why should the renminbi be such a prominent issue in the United States? The obvious answer is the magnitude of the U.S. current account deficit and in particular America's bilateral deficit against China and Asia. Mainstream models point to the need for a substantial fall in the dollar to bring that deficit down to sustainable levels. 2003-4 saw the dollar fall substantially against the euro but only very modestly against Asian currencies. Beijing's continued maintenance of its dollar peg was widely cited as a reason for the reluctance of other Asian countries, which compete with China in third markets, to see their currencies rise.

For China the priority is different. Its need is to better tailor money and credit conditions to the state of Chinese economy. And the conditions that flow from a policy of pegging the renminbi to the dollar at 8.2770 and importing monetary conditions from the United States are no longer obviously appropriate. A manifestation of this is the rapid rate of growth of bank credit, by 17 per cent in 2002 and 20 per cent in 2003, a period when U.S. interest rates were unusually low. Producer price inflation in 2003 accelerated to nearly $2 \frac{1}{2}$ per cent. CPI inflation in 2004

\footnotetext{
${ }^{1}$ Prepared for the Asian Economic Panel, Hong Kong, April 2004. This revision is dated March 2005. I thank Sudarat Ananchotikul, C. Fred Bergsten, Gordon de Brouwer, Lui Hongzhong, Nicholas Lardy, Yingyi Qian, Eisuke
} 
then ran at 3.9 per cent, and according to its Quarter 42004 monetary policy report the People's Bank of China (PBOC) forecasts the rate for 2005 as accelerating further to 4 per cent. Here the decline of the dollar and hence of the renminbi against the euro, yen and other currencies, which means higher import prices and additional demand pressure, has not been helpful. There would seem to be a prima facie case for a tighter monetary policy rather than one that is dictated by the currency peg.

Chinese officials recognize these arguments but are reluctant to adopt a significantly more flexible exchange rate now. They worry that altering the rate will disturb expectations, discourage adjustment and growth, and further undermine the stability of the banking system. While acknowledging the need to eventually have a more flexible exchange rate, they prefer to delay the transition until the financial system has first been strengthened and the capital account has been liberalized further, creating a deeper and more liquid foreign exchange market. Contrary to their views, I argue in this paper that further delay is likely to be a mistake.

The other question, in addition to timing, is what kind of more flexible rate. I argue that the best strategy for China is a form of open-economy inflation targeting in which the authorities formulate monetary policy to limit deviations of inflation and growth from their respective targets. This will not imply neglect of the exchange rate; rather, it will mean intervening to limit currency fluctuations, since the exchange rate influences both inflation and economic growth, the key arguments of the central bank's objective function. In practice, then, such an arrangement will combine an increase in flexibility, which will have benefits for the reasons described in this paper, with limits on the extent of actual volatility. It will also avoid specifying hard targets at which speculators can shoot as the capital account grows increasingly porous.

It is important to emphasize that my argument for a rapid transition to a more flexible

Sakakibara, George von Furstenberg, and John Williamson for helpful comments. 
exchange rate is not also an argument for rapid capital account liberalization. While there are differences of opinion over how rapidly China should move to a more flexible exchange rate, there is virtually no disagreement among scholars that the country should go slow on capital account liberalization. Unfortunately, the same distinction has not always been drawn by officials. U.S. Treasury Secretary Snow, the rest of the U.S. Government and other G-7 deputies, in private meetings with Chinese officials, have reportedly urged China to both freely float the renminbi and open the capital account. This is inappropriate and infeasible. When one contemplates a heavily managed float, which is the only kind of float that is likely to be appropriate and feasible, then any argument concerning necessary links to further capital account liberalization no longer applies.

\section{Costs and Benefits of the Currency Peg}

In the 1950s and 1960s, although China pegged to the U.S. dollar and then to the British pound, the exchange rate had little relevance for trade and resource flows, the vast majority of which were directly controlled. With the breakdown of Bretton Woods, the country's single currency peg was then replaced by a broad basket. In 1981 China devalued what had become a massively overvalued rate and temporarily introduced a separate, so-called official rate for nontrade (mainly remittances and tourism). ${ }^{2} \mathrm{~A}$ de facto multiple exchange rate system was introduced in 1985-6 when the authorities sanctioned a formal secondary market for foreign exchange (on which foreign currency retained by exports could be traded). In 1994 China unified the RMB at the then prevailing rate to the dollar of 8.2770 , which then appreciated very

\footnotetext{
${ }^{2}$ The former was the so-called internal settlement rate of RMB2.8, which applied to all trade transactions. The official rate at the time was RMB1.5. The official rate, which gradually depreciated after the introduction of the internal settlement rate, continued to be used for non-trade transactions. The internal settlement rate was abolished at the end of 1984 when the official rate reached RMB2.8. See Lardy (2002).
} 
modestly to 8.27 in 1995, where it then remained (see Figure 1). In the second half of the 1990s, as part of developing a system of direct monetary control, the growth of the money stock began replacing credit ceilings as the intermediate target of the PBOC, and a unified interbank money market began operating in Shanghai. The PBOC then introduced open market operations, which have now played a role in monetary management for more than five years. Qualified commercial banks and other financial institutions are authorized to trade treasury securities and to quote buy and sell rates for foreign exchange within a plus and minus 0.3 per cent band. ${ }^{3}$ In practice the PBOC has intervened to limit actual fluctuations to plus or minus 0.1 per cent. (See Figure 2.)

Benefits of the peg. The pegged exchange rate is valued for the stimulus it provides to export-led growth. In adopting the Asian model of export-led growth supported by a competitively valued exchange rate, China is pursuing a strategy previously followed by Japan, South Korea, Taiwan, Singapore, Thailand and other Asian economies. In recent years, exports have been far and away the fastest growing component of Chinese GDP, rising at rates in excess of 20 per cent per annum. China's utility as an export platform is also a key attraction for the foreign direct investment that has been so important for the country's economic development.

No doubt exchange rate stability eases planning and eliminates what is at least a minor inconvenience for multinational companies and, more importantly, for the domestic private enterprises that play a growing role in the country's export drive. But econometric studies of the impact of exchange rate variability on foreign trade and investment detect at best small effects. ${ }^{4}$ The rapid growth of Chinese exports and the incentive for foreigners to engage in direct investment reflect more than just the level of the exchange rate. Reform in China and the

\footnotetext{
${ }^{3}$ However, interest rates on loans to small and medium size enterprises and rural credit cooperatives remain subject to administrative guidelines.

${ }^{4}$ A comprehensive survey is Cote (1994). This is in contrast to the results of studies of currency unification (e.g. Rose 2000), which detect larger effects from what is a monetary experiment of an entirely different kind.
} 
country's entry into the World Trade Organization coincided with a rise in global outsourcing made possible by advances in information and communications technology. China is an attractive locale for outsourced production because of its abundant supplies of labor (including, increasingly, skilled labor), long coastline, and large potential market. A modest change in the level of the exchange rate and/or a permanent shift to a somewhat higher level of exchange rate variability might moderate export growth slightly in the short run, but they would do nothing to alter these favorable fundamentals.

Multinationals, for their part, can protect themselves from the effects of exchange rate variability by building diversified portfolios of production facilities and by sourcing from a number of different countries. ${ }^{5}$ Multinational companies' joint venture partners do not enjoy the same diversification (although we are now beginning to see some Chinese companies going abroad), but if temporary appreciation of the exchange rate causes them financial difficulty they can still obtain assistance from their joint-venture partners. They are unlikely to be liquidity constrained, in other words. There is thus no reason why a more flexible renminbi should make life significantly more difficult for such companies.

Note that we are talking here about the majority of Chinese exports and two thirds of recent export growth. The share of China's total exports accounted for by foreign owned enterprises has risen from 28 per cent in 1993 to 41 per cent in 1996 and 54 per cent 2003. (See Figure 3.) In effect, 65 per cent of the increase in China's exports over this period came from multinationals' China subsidiaries and joint ventures. For a country where foreign investment enterprises and joint ventures account for the bulk of exports, the impact on exports of a slightly

\footnotetext{
${ }^{5}$ A change in the level of the exchange rate is another matter, but given the importance of imported inputs and components in their production, even the impact of this is likely to be limited. Jorian (1990) studied U.S.

multinationals and found that their returns are significantly affected by exchange rate fluctuations in only one in ten
} 
more volatile exchange rate should be relatively weak.

The main place to worry about the impact of greater exchange rate variability is private domestically owned firms, which have been allowed to export directly since 1999 (instead of having to go through state-owned trade companies). These enterprises are least able to protect themselves from exchange rate changes. If currency appreciation causes them financial distress, they will have to seek help from the banking system. One can reasonably question whether China's banking system is up to the task - in particular whether its credit evaluation procedures are adequate for distinguishing temporary from chronic problems among its clients. But the impact should not be exaggerated. The share of private domestically owned firms in total exports is still less than 10 per cent. ${ }^{6}$ And, insofar as a large share of export content takes the form of imported components even for private domestically owned firms, changes in the exchange rate affect both costs and revenues in the same direction and therefore do not give rise to severe financial difficulties.

Costs of the peg. None of this is to deny that a more flexible exchange rate will complicate life for private domestically owned firms. But the new regime will also have significant benefits. In particular, the PBOC will be better able to limit procyclicality of money and credit. Under a pegged rate, positive shocks to productivity and growth lead to positive shocks to supplies of money and credit. Any incipient rise in domestic interest rates, which would damp down the surge in economic activity, is at least partially offset by capital inflows or declining outflows. Chinese officials tend to deny the existence of this link, since the country has controls limiting the ability of banks and corporations to arbitrage domestic and foreign interest

cases. A more recent study by Ihring and Prior (2003) updates the data and disaggregates the data but succeeds in raising this fraction of firms to only 17-23 per cent.

${ }^{6}$ The aforementioned exports of foreign-investment enterprises and exports of state-owned enterprises together account for the rest. 
rates. If the authorities wish to limit the rate of growth of bank credit and raise the level of interest rates relative to those prevailing abroad, they can simply issue sterilization bills, thereby sopping up the additional domestic liquidity, and issue directives to the banks instructing them to lend less, as they did in 2004.

But as the capital account grows more porous, tightening domestic credit conditions by selling short-term bills and three-year sterilization bonds just strengthens the tendency for capital to flow in. While the PBOC has been working hard to sterilize capital inflows, it has been only partially successful. And as the Chinese economy is further liberalized, there develop an increasing number of additional channels, other than the banking system through which capital can flow in from abroad and have an impact on the domestic economy. Foreign multinationals can bring in additional funds and use them to purchase apartments as well as engage in industrial investment. Overseas Chinese can engage in similar transactions while on holiday on the mainland. Foreign banks are increasingly able to engage in such transactions as they gain a foothold courtesy of China's WTO membership.

Recent studies have confirmed the existence of a surprisingly strong link between monetary conditions in China and the United States. Ouyang and Rajan (2005) estimate the offset coefficient (the impact of a change in net domestic assets on net foreign assets) by twostage least squares on data starting in 1995 , obtaining a coefficient of 0.5 , indicating that about half of any domestic monetary impulse is offset by induced capital flows. It is safe to assume that this coefficient has been trending upward over time. Cheung, Chinn and Fujii (2003) analyze monetary and financial linkages between China and the United States (as well as Hong Kong and Taiwan) over the period 1996-2002, taking the magnitude of the real interest differential as a measure of integration. They report that the real interest differential trends downward over time 
and "surprisingly positive" evidence of integration with the United States. Decomposing the real interest differential into the uncovered interest differential and the relative purchasing power parity differential, they find that a downward trend in the former is mainly responsible for the shrinking real interest differential vis-a-vis the United States. The persistence of these differentials confirms that Chinese capital controls continue to bite, but their declining magnitude at the same time suggests that financial integration is growing increasingly tight, limiting Chinese monetary autonomy so long as the currency remains pegged.

The result is to amplify the economy's boom and bust cycles. The $\$ 35.8$ billion of nonFDI capital inflows received by China in 2003 (amounting to 2.7 per cent of GDP), at the same time the economy was booming ahead, provides clear evidence of the linkage. In this episode, property-market arbitrage has been the mechanism linking domestic and foreign financial conditions. The expectation is that property prices in Shanghai will eventual converge to those in Hong Kong and Taiwan. Low interest rates in these other markets, which have sustained property price increases there, also thereby fuel price increases in China. When the authorities try to tighten up on bank lending to the property market, funds for real estate speculation instead flow in from abroad, as foreign investment enterprises divert authorized inflows into property purchases, as overseas Chinese repatriate their funds, and through a variety of other mechanisms. Another manifestation of the same problem is the growing tendency for Chinese commercial banks to balk at buying (at prevailing interest rates) the bills that the central bank issues in its effort to sterilize the impact of financial inflows on the domestic money supply (see the discussion in the Financial Times, 30 December 2003, p.10). The more that state banks are commercialized, the less will become the scope for using direct pressure to guide bank lending, and thus the rate of growth of the broad money supply. The very strong correlation between M2 
and foreign reserves since late 2001 is additional evidence that inflows have not been fully sterilized and instead have found their way into the banking system (Ong 2004).

Pegging the currency therefore limits the scope for moving to a market-based monetary policy since it limits the extent to which monetary conditions can move independently. In the present context, this shows up in rising real estate, commodity and shipping prices. A weaker dollar does not help: effective (trade-weighted) depreciation and rising import prices are not helpful when the authorities' task is to combat inflation.

The peg also prevents the authorities from moving to a regime in which interest rates are used to allocate credit. Indiscriminate property lending is again the most obvious manifestation of the consequences. Property lending has been expanding by 25 per cent per annum, causing investment in real estate to rise 30 per cent year on year. To date, property prices have risen somewhat less rapidly, reflecting the elasticity of the supply response, although there are signs that the property market is heating up; at the time of writing real estate prices in Shanghai are reportedly rising at a 30 per cent annual clip. Another manifestation of this resource misallocation is the government's massive accumulation of foreign reserves, resources that are disproportionately held in low-yielding foreign government securities rather than being devoted to high yielding private investment, or for that matter desperately sought-after domestic consumption. These are more signs that the authorities' inability to tailor domestic financial conditions to local needs results in a misallocation of resources.

Then there are the implications for the banking system. In 2002, a period of unusually low interest rates in the United States, bank deposits in China rose by more than 15 per cent. Given the growing reluctance of the commercial banks, as noted above, to purchase the bills used by the authorities to sterilize the effects of financial inflows, bank credit surged by 17 per 
cent. This was unhelpful in a period when questions were already being raised about the quality of investment and the sustainability of rapid growth. ${ }^{7}$ It is inconsistent with efforts to raise bank loan standards since, other things equal, a larger volume of loans is an indication of a decline in their quality on the margin.. It has encouraged the explosive growth of property lending; consumer loans, of which over 80 per cent are home mortgages, now constitute 11 per cent of total bank loans. They accounted for almost 25 per cent of total loan growth in 2004 despite the imposition of stricter controls on mortgage loans ( $\mathrm{Ng} 2005)$. This creates vulnerabilities for the banking system that will be disturbingly familiar to observers of other countries.

The expedients used by the authorities have not been very effective at moderating these pressures. Increasing reserve requirements for commercial banks puts upward pressure on interest rates but only attract additional capital inflows, given the permeability of the capital account. This is evident in the acceleration in the growth of base money following the first rise in reserve requirements. The same is true of the contractionary open market operations implemented through sales of central bank bills on the interbank market.

A radical tightening of capital controls is the one guaranteed way of reconciling domestic monetary autonomy with maintenance of the currency peg. But the authorities have been moving in the other way; they are committed to further opening the capital account prior to moving to a more flexible exchange rate. Beginning on Oct 1, 2003, they authorized Chinese residents to purchase foreign exchange worth U.S. $\$ 3,000$ for each trip abroad, up from the previous limit of $\$ 2,000$. (The amount for those who stay abroad for half a year or longer is an even higher $\$ 5,000$.) They have also liberalized restrictions on the ability of Chinese residents to enter the Hong Kong stock market. They have loosened requirements for exporting enterprises to

\footnotetext{
${ }^{7}$ The rapid rise in money supply and bank credit in 2003 and 2004 was fueled not merely by the productivity and growth shocks that are the subject of this paragraph but also by anticipations of RMB revaluation (making for a less
} 
surrender their foreign exchange earnings. They have allowed local companies involved in international project contracting and labor services to keep foreign exchange income from the previous year instead of having to surrender it to the authorities. They have relaxed restrictions on the ability of Chinese companies to undertake direct investments abroad. They are allowing Chinese insurance companies to add foreign assets to their investment portfolios. They are considering a Qualified Domestic Institutional Investor Program that would permit Chinese institutions to invest in stock and bond markets abroad. Because of the unsatisfied demand for portfolio diversification on the part of Chinese residents, it is hoped that such measures will encourage a modest capital outflow and lead to somewhat tighter conditions on domestic financial markets.

But the same channels that convey outflows can also convey inflows. If anything, the Chinese authorities have encouraged this process by relaxing restrictions on selected capital inflows at the same time that they have attempted to facilitate outflows (Zhang 2003a). For example, they have signaled a readiness to authorize renminbi-denominated bond issuance by the International Finance Corporation and the Asian Development Bank. On the eve of the Communist Party Conference in 2002, they agreed to implement the Qualified Foreign Investor Program, which allows selected foreign investors access to China's domestic equity and debt markets. Note that foreigners engaged in portfolio investment in principle have the option of repatriating their investments on demand.

All this means that the measures taken by the authorities do little to insulate domestic markets from global financial conditions. If anything they have the opposite effect. This has hindered efforts to raise lending standards in the banking system and heightened the fragility of the currency peg, as evident most recently in the massive capital inflows motivated by

clean comparison than the data for 2002). 
expectations that it will not be possible for the authorities to maintain the peg indefinitely.

\section{What Kind of New Regime?}

Assume that the case for a change in China's exchange rate is granted. What then should be the nature of the adjustment and the form of the new regime?

A Step Revaluation. A substantial one-time revaluation would diminish protectionist pressure in the United States. It is also an obvious way of cooling off the Chinese economy and fighting inflationary pressure. But a step revaluation would not address the other problems with the peg. Once prices and costs adjust, earlier problems would simply recur. The authorities would have acquired no greater ability to tailor financial and foreign-exchange-market conditions to domestic needs.

And revaluing once, by undermining the belief that the level of the exchange rate is the

linchpin of policy, will encourage expectations that the authorities might revalue again. This will only worsen the problem of speculative capital flows, in turn amplifying the procyclicality of monetary conditions. To defend the new level of the exchange rate, the authorities will have to deny that they have any intention of revaluing again, even if domestic and international disequilibria become relatively severe. Every system of pegged but adjustable exchange rates has grown increasingly rigid and unadjustable over time, as the authorities have been forced to reassure the markets that their early resort to exchange rate changes will not be repeated. Insofar as China's capital account will inevitably become more porous, the problem will worsen. For all these reasons, a one-time adjustment would only compound the exit problem. ${ }^{8}$

Another problem with a step revaluation is that there will be serious fallout if the 
authorities get the magnitude wrong. A revaluation that is too small will only excite expectations of a further revaluation in the not very distant future, which will worsen the problem of speculative inflows and procyclical monetary conditions. One of the first rules of currency policy is not to make administered changes in exchange rates too small; the problem in the present case is knowing what too small is.

At the same time, a one-time revaluation that is too large could unnecessarily slow the growth of the Chinese economy. Garber (2003) estimates that a 10 per cent revaluation would destroy (or prevent the creation of) half a million industrial jobs. Since the change in the exchange rate would presumably be one time, job creation would resume subsequently. But even a temporary slowdown in urban job creation could fan political unrest, thereby undermining investor confidence. Some estimates put China's unemployment rate at as high as 15 per cent of the labor force; this means that dimming hopes of future employment cannot be taken lightly as a political matter (given that only one in seven members of the labor force has any form of unemployment insurance). ${ }^{9}$

Thus, the fundamental problem with the step revaluation strategy is knowing the appropriate amount by which to revalue. Estimates of the extent of the renminbi's undervaluation are all over the map. For example, relative to its average between the middle of 1996 and the middle of 2002, the RMB is undervalued on a real effective basis (weighted relative to the relative labor costs of its principal trading partners) by only about 5 per cent. (See Figure 4.) This estimate is consistent with the conclusions of IMF Executive Directors in November 2003 that

\footnotetext{
${ }^{8}$ If the Chinese authorities were prepared to tighten capital controls, the story would then be different. But such a policy would run counter to their stated intentions and recent actions (as noted above), not to mention with trends in the vast majority of other countries.

${ }^{9}$ That said, the state sector as a result of restructuring has shed some 50 million jobs (and continues to do so at the rate of 7-9 million jobs per annum). This suggests that a currency adjustment that results in the loss of 1 million jobs will not be an unmanageable political burden.
} 
"there is no substantial evidence that the remnimbi is undervalued..." (IMF 2003).

Alternatively, the revaluation needed to balance the current account adjusted for longterm capital inflows is estimated to be on the order of 15 to 25 per cent (see for example Goldstein 2003 or Merrill Lynch 2004). These estimates strike me as too high. Only under very optimistic scenarios will foreign direct investment inflows continue indefinitely at the present rapid pace. Currently, much of the capital inflow into China is speculative, motivated by expectations of revaluation. Once a modest revaluation occurs and especially if the authorities then move to a managed float, introducing a two-way bet, those speculative inflows will subside.

A Step Revaluation with a Shift to a Basket Peg. The step revaluation could be taken as an occasion to replace the dollar peg with a broader basket that includes not just the dollar but also the euro, the yen, and the currencies of China's other principal trade partners. Retaining the peg but just changing its composition would presumably do little to shake confidence. Because the RMB would no longer rise and fall in lockstep with the dollar, its movement in times of dollar depreciation would no longer cause such difficulties for other regions, such as Europe. Because monetary conditions would now be imported not just from the United States but also from other countries, those monetary conditions would presumably be more stable. ${ }^{10}$ Insofar as the sources of imported inputs and the destinations of manufactured exports are growing increasingly diverse, stability vis-a-vis a basket as opposed to the dollar would simplify the country's international transactions overall.

But simply shifting to a basket would not address the other problems created by the maintenance of a currency peg. In particular it would not enhance the ability of the Chinese authorities to tailor monetary conditions to domestic needs.

\footnotetext{
${ }^{10}$ Diversification implying greater stability insofar as monetary policies in different countries are imperfectly correlated with one another.
} 
A Step Revaluation with a Later Shift to a Float. This is the essence of Goldstein and Lardy's (2003) proposal for a two-step adjustment. In the first, step a one-time 15-25 per cent revaluation would be accompanied by only a very slight widening of the fluctuation band slightly. This would then be followed down the road by a shift to a freer float, but only after the financial sector had been strengthened and the capital account had been further liberalized. Floating would allow the currency to adjust to future developments: the exchange rate could adjust upward if Chinese productivity and exports continued to surge ahead, or it could adjust downward if the economy cooled and/or problems developed in the financial sector. Delaying the shift to a freer float until the banking sector was restructured would ensure that exchange rate fluctuations did not give rise to serious financial problems. Delaying it until the capital account had been further liberalized would mean that the foreign exchange market would be more liquid and stabilizing capital flows would be forthcoming.

The appropriateness of a step revaluation of the exact magnitude proposed by the authors can be questioned for all the reasons enumerated above. In addition, all the other drawbacks of the peg will remain if the shift to significantly greater flexibility is delayed. Indeed, if the authorities announce that the step revaluation will be followed by further exchange rate adjustments (presumably in the direction of further revaluation), they may worsen the problem of destabilizing capital inflows (relative to a benchmark in which there was uncertainty about the direction of future exchange rate movements). Moving immediately to a managed float would not create this same danger, since a managed float introduces the possibility of two-way movements in the exchange rate, making it less likely that market participants will all line up on one side of the market.

In addition, Goldstein and Lardy's rationales for delaying the transition to floating and 
therefore for distinguishing the two steps can be questioned. A first rationale is that the Chinese banking system will be unable to cope with the additional stresses of floating. It is undoubtedly true that rapid capital account liberalization would create additional dangers for financial stability. Big banks with extensive nonperforming loans would have an incentive to borrow offshore as a way of gambling for redemption. Knowing that the authorities regarded them as too big to fail, their foreign counterparts would be tempted to lend.

But my argument is not for more rapid capital account liberalization; it is for greater exchange rate flexibility. Most advocates of greater exchange rate flexibility do not also advocate the relaxation of restrictions on the ability of the banks to borrow offshore. To the contrary, they emphasize the need to strengthen supervision and regulation of the banking system and to retain capital account restrictions as a further form of prudential regulation. ${ }^{11}$

Indeed, if continued tight regulation of the capital account prevents the banks from funding themselves offshore in foreign currency, while prudential supervision and regulation prevent them from making foreign-currency-denominated loans to firms in the nontraded goods sector, then there is no obvious reason why limited currency fluctuations should significantly compound the problems of the banks. In contrast to the situation in South Korea or Thailand in 1997, the banks have not been permitted to freely fund themselves offshore, in foreign currency; thus, they do not have significant currency mismatches. (See Table 1.) A substantial share of the banks' capital, recently replenished by the authorities, is nominally denominated in dollars, but this is a bookkeeping convention that is easily changed by officials to prevent them from suffering capital losses in the event of appreciation. The loans of the banking system are not all

\footnotetext{
${ }^{11}$ Thus, it is unhelpful when commentators like S\&P assert that "risk control systems are ill-prepared to deal with rapid liberalization of the exchange rate and capital controls" (www.chinadaily.com, 15 September 2003), for it is not clear that limited exchange rate flexibility presents significant additional risks if capital controls limiting the banks' foreign transactions are retained.
} 
extended to export-oriented enterprises whose ability to repay would be most immediately cast into doubt by an appreciation of the currency. As shown in Figure 5, much of this lending is infrastructure credit, rural credit, and consumer credit. If a more flexible exchange rate allows the authorities to better tailor financial conditions to the economy's needs, moderating boom and bust cycles, then balance sheet risks would become easier to manage, not harder. The banking system would be stabilized so long as significant currency mismatches were avoided.

None of this questions that the problems in China's banking system are serious. Estimates of nonperforming loans are on the order of 40-50 per cent of GDP. Cleaning up this mess should be an urgent priority. Chinese officials appreciate: thus, they have recapitalized two state banks and have unveiled an "incentive-based" approach to reform, in which success at meeting benchmarks is rewarded with further recapitalization and access to capital markets. But the problem will not be significantly compounded by a somewhat more flexible exchange rate, assuming that they continue to go slow on liberalizing the capital account and make progress in strengthening prudential oversight of the banks. In this sense, the banking-sector problem is not a valid argument for delaying the transition to a managed float.

Nor is the fact that full capital account convertibility will not be implemented anytime soon. To be sure, full capital account liberalization will not be feasible until the banking system is cleaned up. But history is replete with examples of countries that have operated managed floats while retaining capital controls of one sort or another. One might point to European countries in the 1930s, or Japan in the 1970s, or Chile in the 1990s, or Brazil and India today.

Still, the idea that a more flexible exchange rate is only feasible once the capital account has been fully liberalized is widely asserted, in disregard of this evidence. One possible justification could be that the currency will be excessively volatile if international financial 
transactions remain controlled. It will not be possible for most residents and foreigners to sell the renminbi when it appreciates temporarily or to buy it on the dip. And because the market is illiquid, its volatility will be greater.

This view assumes that financial speculation is stabilizing and minimizes the possibility of herd behavior and self-fulfilling dynamics like those emphasized in recent models of balance of payments crises. Both assumptions are questionable. This means that it is not obvious in practice that further opening of the capital account would reduce exchange rate volatility, other things equal.

Moreover, this view ignores the fact that current account transactions also generate a supply and a demand for foreign exchange, the balance of which determines the equilibrium price of foreign currency. A look at the international economics textbooks of the 1960s and 1970s (when capital mobility was low) reveals a catalog of models in which exports generate a flow supply of foreign exchange and imports generate a flow demand. ${ }^{12}$ Most importantly, this view ignores that the central bank will remain an important provider of liquidity to the market. Even if the exchange rate is allowed somewhat more flexibility, under any plausible scenario it will still be heavily managed by the PBOC. The central bank will be buying the renminbi in response to temporary depreciations and selling it when the currency starts appreciating to an undesirable extent. The idea that floating should be delayed until the capital account is significantly liberalized in order to limit the currency's volatility would make sense if we were

\footnotetext{
${ }^{12}$ This simple model in which the exchange rate adjusts to clear the current account (or the basic balance, including also long-term capital flows) may be an inappropriate analytical tool for a setting of high capital mobility, but it is a perfectly fine basis for understanding exchange rate determination in a country with capital controls. Presumably a hybrid model is appropriate for a country whose capital controls are only partially effective. And, to the extent that export supplies and import demands are less volatile than financial market conditions, so too will be the exchange rate under such conditions.
} 
talking about a free float. But this is not something that almost anyone has in mind. ${ }^{13}$ Rather, most observers have in mind a managed float where the central bank provides the liquidity that international financial markets cannot.

The other rationale for delaying the transition until the capital account has been significantly liberalized is that capital controls prevent firms from using financial instruments to insulate themselves from the effects of currency fluctuations. Firms import inputs as part of the process of producing and selling exports; the absence of an onshore market in currency forwards and futures would prevent them from insuring themselves against unexpected currency fluctuations during the production process. Similarly, firms make capital investments now by borrowing domestic currency in order to build the capacity to export later; an unexpected change in the exchange rate that reduces the domestic-currency price of exports can wreak havoc with balance sheets unless the firms in question have foreign-currency liabilities, obtained on foreign financial markets or from foreign financial institutions presuming prudential limits on the currency mismatches of domestic financial institutions. Again, hedging currency exposure in this way will be impossible in the absence of capital account liberalization.

I have already indicated reasons for not taking these arguments too far. The majority of Chinese exports are produced by multinational companies and their joint venture partners, who can self-insure against such risks. In addition, the central bank, by managing the float to prevent excessive fluctuations, will limit financial dislocations for exporters. The literature on "fear of floating" (e.g. Calvo and Reinhart 2002) points to precisely this desire to limit balance-sheet dislocations as an explanation for the prevalence of heavily managed floating in emerging markets.

\footnotetext{
${ }^{13}$ References by, inter alia, Taylor (2003) to a flexible or "market determined" exchange rate regime (which presumably means an exchange rate not influenced by official intervention, as opposed to a managed float)
} 
Moving Now to a Managed Float. These arguments suggest that China should not wait to open its capital account before moving to a managed float. Precisely when to move to greater flexibility is a more difficult question; rigorous analyses of the optimal sequencing of capital account liberalization and exchange rate flexibility are few. Part of the problem is that the capital account regime is treated in the theoretical literature as a dichotomous variable, where in reality there is a continuum of stages of capital account opennness that range from fully closed to fully open. We know that a country with a fully closed capital account has good reason to peg its currency. Hedging opportunities for exporters and importers being nonexistent, flexibility would be disruptive. We also know that a country with a fully open capital account will want to move to some form of greater exchange rate flexibility, except in a few very exceptional cases (like the case of Hong Kong, discussed below). Indeed, authors like Fischer (2003) regard moving to managed flexibility as an essential precondition for full capital account liberalization.

My own view is that capital account liberalization has gone far enough that China should move now to a more flexible exchange rate. The events of 2002-3 and econometric studies like Cheung, Chinn and Fujii (2003) suggest that the capital account has grown sufficiently porous to seriously limit the authorities' room for maneuver. ${ }^{14}$ And, given the risks of attempting to reconcile a liberal capital account with a pegged exchange rate, going further in the direction of capital account liberalization before moving to greater currency flexibility would create more problems than it solves.

In addition, experience suggests that when the capital account becomes moderately open, there is a spontaneous tendency for it to open further. Remaining controls weaken whether the

unfortunately appear to point in the other direction.

${ }^{14}$ Others, like Merrill Lynch (2004, p.3), reach the same conclusion (e.g. "The 'closed' capital account is clearly showing signs of leakage...Intervention required to offset these flows is simply too large to easily sterilise and, as a result, the external imbalance is generating internal discord"). 
authorities like it or not. Economically, opening some channels for capital flows creates additional avenues through which market participants can evade remaining restrictions. ${ }^{15}$ Politically, allowing residents and foreigners to engage in some international financial transactions creates interest groups that lobby for the removal of restrictions on other such transactions. In China's case, the simple fact that the country is becoming more integrated with the global economy, leading to its accession to the World Trade Organization, creates obligations - such as national treatment for foreign banks - implying a more porous capital account. All these are reasons for the Chinese authorities not to delay in moving to a managed float Moving directly from the peg to a managed float will simplify the adjustment to the new regime. It will diminish the need to assume that the authorities somehow know the precise magnitude of any overvaluation. If the initial decision is to allow the currency to drift up by, say, 5 per cent, but this turns out to do too little to slow the accumulation of reserves and to prevent the economy from overheating, then the authorities can engage in further open market sales to push the exchange rate up a bit further. An initial adjustment that is too small does less to damage credibility, putting the authorities in an unsustainable position, when the new regime is a shift to a market determined exchange rate that can adjust to changing circumstances than when it is a hard-and-fast peg that will supposedly be set and held. Since the currency can appreciate as well as depreciate, speculators will be deterred by the existence of this two-way bet from all lining up on one side of the market, and the problem of anticipatory capital inflows will be less. If economic conditions change and market pressures cause the exchange rate to move, then the authorities can use that information and lean against the wind harder or softer depending on whether they see the change in conditions as temporary or permanent. Thus, shifting to a

\footnotetext{
${ }^{15}$ Studies of other regulated capital account regimes, such as Chile's, generally suggest that their restrictions on capital account transactions have tended to lose effectiveness over time.
} 
managed float does not relieve the authorities of the need to have a view of the appropriate level or range for the exchange rate, although they can now make that view contingent on current conditions and adapt it to new information (this being the essence of what is meant by greater flexibility).

\section{Anchoring Monetary Policy}

While much of this paper, like the surrounding debate, is framed in terms of choice of the exchange rate regime, the real question is the underlying objectives of monetary policy. Once upon a time, when normal instruments of monetary management were unavailable and exports were the only dynamic sector, it made sense to organize monetary policy around the currency peg. Exports determined economic growth and were strongly affected by the exchange rate. At the end of China's period of high inflation, the exchange rate was also the logical anchor for the price level. But these conditions no longer hold. Exports are no longer the exclusive driver of growth; the sources of demand for Chinese production have become more diversified. Price stability is well established, and an exchange rate peg is no longer the obvious focal point for monetary policy. As the capital account has grown more porous, capital displays a greater tendency to flow into the country when domestic and foreign interest rates diverse, limiting the authorities' room for maneuver. And as the economy is liberalized, creating new channels through which foreign capital can flow into the property market and other segments of the economy, the authorities' attempts to regulate money and credit conditions by issuing directives to the Big Four commercial banks becomes increasingly ineffectual.

All this suggests that China needs to move to a more conventional monetary regime where interest rates are tailored to domestic conditions and where they can diverge from world 
interest rates because the exchange rate is allowed to move. That the country possesses an interbank market and a central bank that engages in open market operations suggests that it is possible to regularize monetary policy in this way. Some will object that China lacks marketdetermined interest rates - that lending and deposit rates are still set by the central bank. However, on January $1^{\text {st }}, 2004$, banks gained greater flexibility in terms of setting rates at variance with the central bank's pegs. Even if rates on some loans are still limited by official ceilings, it is rates on market-determined loans to private-owned firms and other customers that matter on the margin. And to the extent that increasing amounts of credit in any case circumvent the banking system completely, the absence of market-determined bank lending and deposit rates becomes less of an issue; those credit flows can only be shaped by adjusting interest rates. Another way of putting the point is that the authorities are going to have abandon their practice of setting bank lending and deposit rates at non-market levels sooner rather than later.

To say that the PBOC should focus on growth and inflation does not mean that it can neglect exchange rate movements. How much weight it should put on the exchange rate in its reaction function and how widely the currency should be allowed to fluctuate should depend, in standard open-economy fashion, on the responsiveness of growth and inflation to shocks and the nature and magnitude of the specific shocks to which the economy is exposed (see e.g. Ball 1999). To repeat, the PBOC should think of itself as maximizing an objective function whose arguments are deviations from the target rate of inflation and the sustainable rate of growth.

To many, this regime will sound like an informal version of open-economy inflation targeting, which of course is what it is. I am not arguing that China should immediately adopt the full apparatus of formal inflation targeting complete with issuance of an inflation report and a transparent policy making process. It is unlikely that Chinese officials would welcome the 
requisite levels of transparency. But it is not clear that the entire formal apparatus is required to make this regime a success. In fact, countries like Peru which have adopted the relevant objective function and monetary policy operating strategy without also installing the complete apparatus have shown that this informal approach to inflation targeting can work. The PBOC already forecasts inflation and growth. China does not suffer from a problem of fiscal dominance like that which has prevented the operation of such regimes in other times and places. ${ }^{16}$

How much the exchange rate moves in this new regime will depend on the nature of shocks. Since these vary over time, it makes no sense to frame policy in terms of a time invariant fluctuation band. Thus, I do not see widening the width of the current fluctuation band as an effective way for the Chinese authorities to enhance their monetary control. If the band is widened slightly, say from plus-or-minus 0.3 per cent to plus-or-minus 3 per cent, there will remain the potential for conflict between the immediate goal of limiting exchange rate flexibility and the deeper objectives of achieving low inflation and sustainable growth. It then may be necessary to again shift the central parity, with all the difficulties and undesirable properties of a step revaluation. If the band is widened significantly more than this, then it will no longer serve as a guide for monetary policy (as I argue in this paper it no longer should). It is then best done away with.

This is where I differ from Goldstein and Lardy (2003), who argue for retaining a relatively narrow tolerance interval for fluctuations and an exchange-rate centered monetary policy until the financial sector is first strengthened and the capital account is opened further.

\footnotetext{
${ }^{16}$ To be sure, the weakness of the state enterprises and, especially, the banking system mean that the likelihood of such problems down the road should not be minimized. If those problems are put off until they finally explode, with serious adverse consequences for public-sector finances, the PBOC's commitment to low inflation could be placed at risk. But so too would be any other monetary policy regime, including one predicated on the continued maintenance of a currency peg. These problems are not arguments against a more flexible exchange rate per se. But they are an argument for resolving problems in the state-enterprise and banking sectors as quickly as possible so that the pursuit of a stable monetary policy, whatever the regime, is not placed at risk.
} 
Some will say that my argument for a managed float and their's for an exchange rate band are not really that different. After all, Chinese officials already refer to their very narrow band against the dollar as floating. Still, I differ from Goldstein and Lardy is in advocating the immediate abandonment of an exchange-rate centered monetary policy and a higher degree of exchange rate flexibility than they believe the Chinese economy would benefit from at the present time.

To repeat, shunning a band need not mean that the exchange rate will fluctuate wildly. The rate should be managed to limit the currency's movement. But the extent of permissible fluctuations should be a function of the shocks to which the economy is subjected, not of the width of a predetermined fluctuation band.

Abstractions are well and good, but the proof of the pudding is in the eating. What do these observations imply for the actual conduct of monetary policy in March 2005, when this paper was completed? The PBOC was forecasting a CPI inflation rate of 4 per cent and an economic growth rate of 8 per cent. To most observers this implied the need for modest monetary tightening to damp down inflation. Given the linkage between domestic interest rates and foreign interest rates documented by Cheung et al. (2005), this in turn implies the need for single-digit appreciation against the dollar (assuming no other changes in prevailing conditions, an assumption to which I return below). This would help to cool down inflationary pressures without slowing growth more than marginally. It would not necessarily balance China's current account, but then current account balance is not an appropriate target for monetary policy. While it will not solve the U.S. current account problem, the solution to that problem must be found in the United States, not in China.

At the time of writing, a number of observers are forecasting the need for a significant 
additional decline in the dollar to narrow the U.S. current account deficit. Calculations in Obstfeld and Rogoff (2004) suggest, for example, that the dollar may have to fall by another 30 per cent on a trade-weighted basis to return the U.S. current account to a sustainable path.

Whether this adjustment will occur gradually over time or all at once is hotly debated. We need not resolve that debate here. The point is that which outcome obtains has implications for Chinese monetary and exchange rate policy. If the dollar falls by a few percentage points a year going forward, that will not have first-order implications for Chinese monetary policy. But if it falls by 30 per cent tomorrow, that would have major implications for the appropriate value of the renminbi against the dollar. Quickly following the dollar down by 30 per cent or more against the euro and the yen (more, actually, since if China follows, the dollar will then have to fall by still more against those currencies in order to achieve a 30 per cent depreciation on a trade-weighted basis) would fan demand and inflation. This is a perfect illustration of why it is not sensible to focus discussions of policy reform on the magnitude of China's step revaluation. By how much the renminbi should be allowed to float upward against the dollar should depend, rather, on the shocks to which the economy is subjected - shocks that are intrinsically uncertain. What is essential is for China to obtain the additional flexibility necessary to respond optimally to those shocks. A change in exchange rate regime in the direction of managed floating provides that flexibility. Revaluing the renminbi by, say, 25 per cent against the dollar does not. ${ }^{17}$

\section{Potential Objections}

It is worth reviewing other potential objections to this recommendation. First, it is argued

\footnotetext{
${ }^{17}$ This particular mental experiment, which assumes that the dollar will fall against the euro and the yen, also reminds us that it makes more sense for the Chinese authorities to gauge the stance of policy in terms of a basket rather than vis-à-vis the dollar alone. But even if we consider a basket peg, a one-time revaluation provides less flexibility for responding to future shocks than moving to a managed float.
} 
that China should not abandon a peg that served it so well in the 1997-8 Asian financial crisis. In fact, what really helped China in the crisis was not its peg but its capital controls. ${ }^{18}$ It is unhelpful to conflate them by saying, as did for example Paul Coughlin of Standard \& Poor's (on 16 Sept. 2003, according to www.china.org.cn), that "we learned from the Asia currency crisis in the mid1990s that the combination of a weak banking system, floating exchange rates and free flows of capital can be a very dangerous combination."

Second, it is argued by, inter alia, Garber (2003) that China should not abandon its peg because it still has massive amounts of underemployed labor to absorb into the modern industrial sector and continued rapid export growth is the only feasible way of doing so. But this is an argument for a competitive exchange rate, not for a peg. It is an argument against a large step revaluation and in favor of continuing to lean against the wind if the currency shows an undue tendency to appreciate, not an argument against managed flexibility. Indeed, managed flexibility would be useful for preventing serious overheating, like that evident in the final months of 2003, which can result in a boom-and-bust cycle that bequeaths a legacy of nonperforming investments, undermining investor confidence. Such macroeconomic instability would not be good in the long run for the more rapid absorption of underemployed labor in the modern sector.

Third, it is argued that allowing the exchange rate to appreciate would cause substantial capital losses on the country's foreign exchange reserves. ${ }^{19}$ But this is an objection to any change in the exchange rate regime that results in RMB appreciation, not against my particular proposal. To the extent that the present proposal, which emphasizes the need for greater flexibility rather than for a substantial one-time appreciation, might mean a more limited change in the level of the currency in the short run, the consequent capital losses would be less.

\footnotetext{
${ }_{18}$ Although other countries were undoubtedly helped by China's resistance to devaluing.

${ }^{19}$ If China revalued by 30 per cent, the government's losses would exceed the value of annual tax revenues.
} 
Fourth, and finally, there is the argument that the peg is good for China's neighbors and that a more flexible RMB would cause distress elsewhere in Asia. It is to this aspect of the problem that I now turn.

\section{Implications for Other Asian Countries}

Assessing the impact of a change in the renminbi exchange rate on the rest of Asia is no easy task. Not only is there disagreement about how China itself will be affected, but there is confusion about how the impact will be felt by the country's neighbors.

On the assumption that China will continue to experience inflationary pressure, the PBOC will want to tighten monetary policy, which will imply some strengthening of the exchange rate going forward. The result will be to slightly slow the rate of economic growth relative to what would have obtained otherwise. As argued above, the large imported-input component of Chinese exports suggests that the impact on exports will be less than would be the case in a number of other countries. Similarly, the declining dependence of Chinese exports on the low cost of unskilled labor suggests that the impact will be smaller than might have been the case in earlier years.

This change in relative prices will lead to a reallocation of resources from the production of traded to nontraded goods (relative to the benchmark in which the exchange rate remains unchanged). Together with the elasticity of export growth with respect to GDP growth, this suggests that the change in the rate of growth of exports will be larger than the change in the rate of growth of the production of goods and services. (Historically, the change in the export growth rate relative to the change in the GDP growth rate is on the order to 2 to 3.) As export growth and GDP growth slow down at least slightly, so will the volume of inward FDI. 
The rise in relative unit labor costs will accelerate the country's move out of unskilledlabor intensive exports into products where labor costs matter less. It will speed the shift from the production of light manufactures (apparel, for example) into the production of finished capital goods such as data processing and office equipment, telecommunciations equipment, and electrical machinery. ${ }^{20}$

This implies that the impact on the country's Asian neighbors will be uneven. On the one hand, low-income countries such as Cambodia, Vietnam, Bangladesh, Sri Lanka, and Pakistan that compete with China in the production of unskilled-labor intensive light manufactures will benefit from the increase in China's relative unit labor costs and the country's shift into more technologically advanced, higher value-added product lines. These are the countries whose exports, broken down by industry, have the highest rank correlation with Chinese exports. ${ }^{21}$ The same may be true of India, though less so insofar as the two countries specialize in different products (in apparel, for example, India specializes in undergarments while China specializes in outer garments). That China has as many as 200 million underemployed workers in agriculture and state enterprises yet to be absorbed into the modern sector, a significant fraction of whom will find work in export industries, suggests that the impact will not be great. Still, this logic suggests that the least developed Asian countries will benefit, ceteris paribus.

The next tier of Asian countries will also feel the repercussions of higher Chinese labor costs, modestly relieving the pressure felt by their light manufacturing. But they will be less favorably affected insofar as the change in Chinese exchange rate policy will accelerate that

\footnotetext{
${ }^{20}$ I am not suggesting that China will abandon the production of unskilled-labor intensive goods. Continuing reform of state-owned enterprises and agriculture will produce additional effective supplies of unskilled labor, especially in the west of the country. But I am suggesting that these trends will be affected on the margin by a somewhat stronger exchange rate.

${ }^{21}$ See Shafaeddin (2002). One should be careful here, because these rank correlations are based on historical data and the structure of exports is changing rapidly.
} 
country's move up the technology ladder into the product of more sophisticated goods. Here I have in mind countries like Thailand with which China increasingly competes in the production of higher valued-added products like household appliances and electrical machinery. Malaysia is plausibly in this group insofar as it competes with China both in light manufactures like nontextile clothing, furniture and textile yarn and in capital goods (automatic data processing machinery, electrical machinery, semiconductors, telecom parts and equipment, radio receivers and transistors) but has yet to move up the technology ladder to the same extent as Japan and the NIEs. ${ }^{22}$ For present purposes we can assume that the positive impact on unskilled labor intensive industries and the negative impact on more skilled labor intensive industries roughly cancel out.

The region's most advanced economies will feel mainly negative effects. Someday China will compete with them in the production of technologically-sophisticated inputs and capital goods. But that evolution will not be noticeably accelerated by the limited change in China's exchange rate contemplated here. This means that they will feel essentially no impact of the induced increase in Chinese labor costs. The main way they will feel the change in exchange rate policy is as a deceleration in Chinese growth (relative to what would have happened otherwise) which will reduce the demand for their exports of capital goods. ${ }^{23}$ Here I have in mind exports from Japan, Singapore, South Korea and Taiwan of parts and components for the assembly of consumer electronics and IT hardware (but also high quality textiles, machinery, equipment, and petrochemicals used in the production of other manufactures). ${ }^{24}$ In the first nine months of 2003 , China accounted for 36 per cent of total export growth in the case of South Korea, 32 per cent in

\footnotetext{
${ }^{22}$ Some might also put Indonesia and the Philippines in this category.

${ }^{23}$ As Kanno (2003, p.14) writes, "[i]f China's capex-driven growth were to slow, Japan would suffer" (Kanno 2003, p.14). 10 per cent of Japanese exports went to China in 2002, up from 5 per cent in 1995 . China accounted for 39 per cent of Japan's export growth in 2002 and 32 per cent in 2003.

${ }^{24}$ Textiles are a good example. Japan, Hong Kong, Taiwan and Korea export high quality textiles to China as inputs into its exports of clothing. They benefit from low labor costs there, while lower income countries suffer (Ianchovichina, Suthiwart-Narueput and Zhao 2003).
} 
the case of Japan, and 68 per cent in the case of Taiwan. ${ }^{25}$ This is one basis for forecasting how these countries will feel the change in the rate of growth of Chinese manufacturing and exports. This picture can of course be made more complicated by those with a taste for detail. For example, some of Asia's less developed countries export not only light manufactures to third markets but also energy products and agricultural staples to China; they will therefore feel some negative effects from the deceleration in Chinese growth. ${ }^{26}$ Still, the basic story implies an improvement in international competitiveness for Asia's low income countries, a negligible net impact on the middle tier, and a negative impact on the upper tier.

Note that the implications of this analysis of regional repercussions are very different than suggested in prior discussions. For example, contrary to the presumption of Bergsten (2004), it is not clear that a stronger renminbi will cause the dollar to depreciate against the currencies of the other advanced Asian economies (Japan, South Korea, Singapore, and Taiwan). ${ }^{27}$ In addition, there is unlikely to be much impact on the currencies of middle-income Asian countries whose exports to the United States are also growing rapidly. This has obvious implications for the debate over global adjustment. A further argument, often heard, for allowing the RMB to adjust upward is that China, in formulating its exchange rate policy, should consider not just its own internal needs but also the global implications. As an increasingly large player on global markets, the country should be aware of its responsibility for the constructive correction of global imbalances. Conventional wisdom on this topic holds: first, that Asian currencies need

\footnotetext{
${ }^{25}$ Preliminary data. In the ASEAN countries, in contrast, the China share was 20-30 per cent. This reinforces the preceding point about how ASEAN ex Singapore on the one hand and Japan, South Korea and Taiwan on the other will feel quite different effects.

${ }^{26}$ This is likely to be especially true of Indonesia, whose exports are relatively natural resource intensive (the country exports energy, timber, oilseeds, sugar and cotton to China). Thailand and Vietnam will also be hurt by slower Chinese growth insofar as they export cereals to that country.

27 "Korea, other Asian countries and even Japan are understandably reluctant to let their currencies rise against the dollar when doing so would produce an equivalent rise against the renminbi, the money of their toughest
} 
to appreciate against the dollar in order to help correct the U.S. current account deficit without placing intolerable pressure on the European economy; and, second, that with appreciation of the RMB against the dollar, other Asian countries will be willing to allow their currencies to appreciate against the dollar as well. ${ }^{28}$ In fact, the analysis here suggests that appreciation of the renminbi will not put upward pressure on the yen, won and new Taiwan dollar. Whether the net effect of a stronger renminbi, including these additional repercussions, would be positive or negative for the U.S. current account deficit is uncertain. In my view, the main argument for a change in Chinese exchange rate policy stems from China's own domestic needs, not from any responsibility the country might have in helping to solve America's current account problem. For the United States, the solution to that problem lies at home.

The magnitude of the effects on the rest of Asia should not be exaggerated. Given the high imported-input content of Chinese exports of consumer electronics and IT hardware (as high as 84 per cent by some estimates), it is unlikely that the rate of growth of Chinese exports will slow dramatically even in the wake of a large devaluation. Hence there is unlikely to be a large impact on the country's neighbors. But what is critical to my discussion is not the magnitude but the direction of the effects - since previous analyses have suggested that an RMB revaluation will lead to a generalized revaluation of Asian currencies.

Four sources of evidence are consistent with my conclusions. First, there are simulation analyzes of the impact of China's emergence on the trade and growth of other countries, which generally take China's accession to the WTO as the comparative-statics experiment under

competitor" (Bergsten 2004, p.3). This no longer follows if the exports of China and these countries are complements, not substitutes.

${ }^{28}$ Bergsten (2003) argues that if China revalued by 20-25 per cent, then South Korea and Taiwan and perhaps other Asian economies could participate in the necessary global adjustment by letting their rates float upward by 10-15 per cent against the dollar. He suggests that the yen could rise even further against the dollar because of Japan's continuing balance of payments surpluses. My analysis suggests that these currencies might weaken rather than strengthening, with entirely different implications for the U.S. balance of payments. 
consideration. To a first approximation, the effects of China's accession to the WTO increases its export market access -- and the access of other suppliers to China's home market -- thus operating like a revaluation in reverse. Thus, Ianchovichina and Walmsley (2001) find that China's WTO access reduces the exports and therefore the GDP of Vietnam, the Philippines, Thailand and Indonesia and Malaysia (due mainly to the negative impact on their textile and apparel exports). A revaluation, which would raise Chinese labor costs and reduce the country's competitiveness in these sectors, would have precisely the opposite effects. They find that WTO accession would have a positive impact on exports of Japan and the NIEs (Hong Kong, South Korea, Singapore and Taiwan), due mainly to the increase in their exports to China of high quality textile and electronics inputs (along with miscellaneous exports of processing industries). ${ }^{29}$ Again this suggests that an RMB revaluation would have a negative impact on these countries. On the other hand, their simulations suggest a decline in exports (mainly of textiles and apparel) and a reduction in GDP relative to baseline levels in East Asia's developing countries. Similarly, Yang and Vines (2000) simulate the impact of China's growth on exports from other developing countries, finding that those of the ASEAN countries dropped slightly while those of Japan and the NIEs both rose. ${ }^{30}$ Again, note that a stronger RMB that translates into somewhat slower Chinese growth in general and Chinese export growth in particular is tantamount to running this experiment in reverse.

Second, there is the econometric study of Ahearne et al. (2003), which uses a panel of

\footnotetext{
${ }^{29}$ As they summarize their results, "Japan and the newly industrialized economies in East Asia will also benefit from China's accession to the WTO...As important suppliers of materials to China, these countries will observe an improvement in their terms of trade and returns to capital." In both Japan and the NIEs, the projected increases in production are driven mainly by expansion in exports to China. Looking closely at their results, it is not clear in fact that this conclusion carries over to Singapore, due to a large and mysterious fall in projected exports of beverages and tobacco.

${ }^{30}$ These overall effects are the sum of positive effects on exports to China itself and negative effects on exports to third markets, which differ in size depending on the Asian exporter concerned - as emphasized in my discussion above.
} 
annual data spanning the period 1981-2000 for four NIEs (Korea, Singapore, Taiwan, and Hong Kong) and four ASEAN members (Indonesia, Malaysia, Philippines and Thailand). ${ }^{31}$ The authors find (p.21) "little evidence that increases in China's exports reduce the exports of other emerging Asian economies. Indeed, it appears that China's exports and exports of the other countries are positively correlated" [emphasis in original]. This is exactly what my argument suggests should be the case for the four NIEs. Since these countries export components for use in China's own export industries, their exports will rise and - as in the case of revaluation - fall with the exports of the latter. Since Ahearne et al.'s four ASEAN members are in the middle tier of Asian countries, one should not be surprised by either a small positive or small negative coefficient on Chinese exports in their case. ${ }^{32}$ My hypothesis suggests that one would find a negative coefficient when estimating the same equation for low-income Asian countries such as Cambodia, Vietnam, Bangladesh, Sri Lanka, and Pakistan. I do not yet know whether this is the case. But note that this is not the sample for which my results would be regarded as controversial. Rather, it is the positive correlation between China's exports and the export performance of high-income Asian countries that the advocates of yen revaluation to achieve global adjustment and U.S. current account rebalancing would regard as so controversial.

Third, there are the simulations that Warwick McKibbin has been kind enough to run using the G-Cubed model, of the effects a 10 per cent appreciation of the RMB (McKibbin and Stoeckel 2003). The G-Cubed Model is a dynamic macroeconomic model with considerable realand financial-sector disaggregation. Critically for present purposes, it distinguishes 12 Asian countries (counting Australia and New Zealand) and disaggregates by sector. These simulations show depreciations in the dollar exchange rates of essentially every Asian country within two

\footnotetext{
${ }^{31}$ Singapore is also a member of ASEAN. Here I am simply following Ahearne et al's categorization.

${ }^{32}$ Note that these effects are only statistically significant when the authors do not control for common shocks.
} 
years of China's revaluation against the dollar, consistent with my forecast. ${ }^{33}$ In addition, the dollar rates of Taiwan, Singapore, and South Korea depreciate by more than those of Indonesia, Thailand and Malaysia, again as predicted here. ${ }^{34}$

Fourth and finally, there is press commentatory. Consider for example the headline and sub-head of story in the January 12, 2004 edition of the Financial Times: "China's growth helping to soak up excess Japanese capacity: Economists say strong demand from China may be weakening deflationary momentum in Japan." 35

Two further issues are worth noting in this context. The first one is Hong Kong. Essentially, Hong Kong is in the same situation as East Asia's other high-income countries, exporting high-quality textiles and other inputs utilized in Chinese manufacturing. Like Japan, South Korea, Singapore and Taiwan, it will suffer from the slowdown in Chinese growth and declining demand for its exports of intermediate goods. In addition, insofar as Hong Kong remains an important entrepot center, any deceleration of Chinese export growth will have an especially pronounced negative impact. On the other hand, there is the fact that Hong Kong stands to benefit disproportionately from the increase in Chinese tourism due to the increased purchasing power of the RMB. The net effect is uncertain.

Then there are the implications for Hong Kong's currency board. Hong Kong's dollar peg has been especially convenient because the renminbi has also been tied to the dollar. When the RMB begins to float, the authorities will undoubted revisit this policy. An economy as small and open as Hong Kong has no wish to float. Pegging to the dollar has proven value but will grow

\footnotetext{
${ }^{33}$ Three of the countries - Japan, Korea and Thailand - see their currencies strengthen slightly against the dollar in the first year, presumably as a function of the redirection of capital inflows away from China and toward the others. ${ }^{34}$ Only marginally in the case of Korea. Japan is the exception to this pattern: its dollar rate depreciates by the least in response to China's revaluation. It appears to have the largest appreciation in the first year, which may be related to this fact (and reflect the capital-flows-diversion effect flagged above).

${ }^{35}$ Kynge and Pilling (2004), p.10. Or see the FT article on 27 January 2004, "Surge in Japanese Exports to China," describing how growing Japanese exports of components to the Chinese economy has been supporting the yen.
} 
less appealing as Hong Kong becomes even more economically interdependent with the Pearl River Delta and less interdependent with the United States. Shifting to a renminbi peg (or adopting the renminbi) is inevitable in the very long run. Yet, in the short run, abandoning the dollar peg would be a considerable shock to confidence. A possible compromise for the medium term would be to contemplate a basket peg with equal weights on the dollar and RMB.

This brings us to the final issue, namely, proposals for a common basket or singlecurrency peg for Asian countries. The fact that the competitiveness and exchange rates of different Asian countries will be affected in different ways also casts doubt on the notion that the region should respond with some kind of collective exchange rate arrangement. A common peg is not obviously desirable for a group of countries that will be affected in opposite directions by by this common shock. A single currency peg for East Asia ex Japan, whether to the yen or the dollar, makes no sense when some countries will see their competitiveness enhanced by the change in Chinese exchange rate policy while others will see their competitiveness decline. A basket peg makes no more sense, insofar as different countries, which are affected in opposite directions, all peg to the same basket. Nor is it clear in which direction a basket with, say, equal weights on the yen, dollar and euro will move. Insofar as capital goods industries in the United States and Europe depend less than Japan's on exports of equipment to China, the deceleration in Chinese growth might lead to some strengthening of the dollar and euro against the yen. Yet even the direction, much less the magnitude, of the resulting change in an equally-weighted basket is impossible to predict.

From this point of view, it makes no sense to attempt to manage Asian exchange rates in the wake of the change in Chinese policy to prevent intra-regional fluctuations. Better than tying monetary policy to the dollar, the yen, a G-3 basket, or one another's currencies would be for the 
monetary authorities of each Asian country to focus on inflation and the output gap and to adjust interest rates and intervene in the foreign exchange market to target desirable levels for these variables. $^{36}$

\section{Conclusion}

The dollar peg has served China well. At a time when the economy was suffering from severe inflationary imbalances, just beginning to grow its exports, and tightly controlling its capital account, pegging the currency made sense. But now that inflation has been brought down to the single digits, exports are roaring ahead, and the capital account is becoming increasingly porous, the case for the peg is less compelling. The authorities need to be able to tailor monetary, financial and currency market conditions to local needs. The costs of not doing so are evident in excessive rates of growth of money and bank credit which create dangers of overheating, investment excesses, and further problems in the financial sector. Serious problems have been averted, so far, by open market operations and regulatory restraints on bank lending. But it is important to recognize that the ability to control money and credit conditions will weaken further as the opening and liberalization of the Chinese economy renders the capital account of the balance of payments increasingly permeable. Open market operations will change the composition of the monetary base but not the rate of growth of the money supply. As more channels develop linking domestic markets to financial markets in the rest of the world, attempting to regulate the growth of money and credit by issuing directives to the banks will become less effective. The authorities will only be able to adjust money and credit conditions to

\footnotetext{
${ }^{36}$ Exactly how much the exchange rate should be allowed to vary will depend both on the structure of the real and financial sectors (the responsiveness of exports, the extent of currency mismatches on balance sheets) but also the nature of the shocks to which the economy is subject. See Eichengreen (2002). It is impossible to answer the
} 
domestic needs if they allow the exchange rate to vary.

Chinese officials acknowledge these arguments but prefer to leave the adjustment for another day. They are reluctant to tamper with success. They fear that a stronger currency could mean slower growth, aggravating the political problems associated with unemployment. They worry about the banks' ability to cope. They instinctually resist pressure from abroad.

Though there is never a convenient time to alter the exchange rate regime, the authorities should ignore ill-timed American pressure and move to a more flexible exchange rate now. The capital account is growing more permeable, independent of official regulations. As Chinese companies do more business offshore and foreign companies do more business in China, there will be even more scope for leads and lags. Accession to the World Trade Organization will open the Chinese market to foreign banks, creating additional channels for capital flows. Political liberalization will make it easier for residents to travel and take money with them. A more porous capital account will make the currency peg even more inconvenient and fragile. It will be harder to move to a manage float without disturbing confidence if the decision is taken under duress, when capital is flowing out rather than flowing in, growth has slowed, and there are open problems in the banking system.

By moving further in the direction of capital account liberalization before adopting a more flexible exchange rate, the authorities are heightening these dangers. They are strengthening the country's dependence on foreign financial conditions and giving the central bank even less leeway to tailor these to domestic needs. They are encouraging procyclical, destabilizing capital flows by creating one-way bets for speculators.

Compared to these costs and risks, the standard arguments against moving to a more

question of how much Asia's managed exchange rates should be allowed to fluctuate without knowing the magnitude of these parameters and disturbances. 
flexible exchange rate are unconvincing. Chinese commercial banks may be awash with bad loans, and their risk-management systems may be inadequate, making bank restructuring an urgent priority, but it is not clear that a somewhat more flexible exchange rate will significantly compound their problems. In contrast, a more porous capital account will heighten these dangers, making it important that this be accompanied by bank recapitalization and strengthened supervision to prevent excessive risk taking. Limits on capital account transactions will prevent enterprises from using financial instruments to hedge against currency fluctuations, but the majority of exporting firms exposed to such fluctuations are multinational enterprises or joint venture partners capable of self-insuring against these risks.

For domestic private companies, these risks can be limited if the central bank manages the exchange rate to prevent excessive fluctuations. Thus, the argument for a more flexible exchange rate is not an argument for a freely flexible exchange rate. For the foreseeable future the best exchange rate regime for China will remain a heavily managed float. The PBOC can conduct open market operations in short-term bills and has an interbank market on which to operate. There is no reason why it should not be able to manage the exchange rate in a manner consistent with its inflation and growth targets.

Because Chinese exports have such a large imported-input component, the impact of appreciation is likely to be less than in many other countries. To the extent that the argument here is for an exchange rate that is gradually permitted to fluctuate more freely rather than for a substantial step revaluation of the currency, the short-run impact on exports will be smaller still. There would presumably be a slight decline in the rate of growth concentrated in periods when the Chinese economy threatened to overheat, but this would be a welcome manifestation of heightened stability. There would be some shift from the production of traded to nontraded 
goods and a somewhat greater tendency for Chinese firms to move toward the production of more skilled-labor intensive, technologically-sophisticated goods, none of which is obviously unwelcome. If the shift to the new exchange rate regime is completed in timely fashion, there is no reason to think that these changes would be overly disruptive.

This in turn suggests that the impact on other Asian countries will not be overwhelming. But those effects will be diverse: they will be modestly positive for the region's low income economies and modestly negative for its high income countries. Insofar as the competitiveness of the two sets of economies is affected in opposite directions, the pressure on their currencies and the desirable direction of exchange rate adjustment will similarly be different. From this point of view, it makes no sense to attempt to manage Asian exchange rates in the wake of the change in Chinese policy so as to prevent intra-regional fluctuations. 


\section{References}

Ahearne, Alan G., John G. Fernald, Prakash Loungani and John W. Schindler (2003), "China and Emerging Asia: Comrades or Competitors?” International Finance Discussion Paper no. 789, Board of Governors, Federal Reserve System (December).

Ball, Lawrence (1999), "Policy Rules for Open Economies," in John Taylor (ed.), Monetary Policy Rules, Chicago: University of Chicago Press, pp.127-156.

Bergsten, C. Fred (2004), “Chinese Currency Controversies," unpublished manuscript, Institute for International Economics (January).

Bhalla, Surjit S. (1998), "Chinese Mercantilism: Currency Wars and How the East Was Lost," ICRIER Working Paper no. 45 (July).

Calvo, Guillermo and Carmen Reinhart (2002), "Fear of Floating," Quarterly Journal of Economics 117, pp.379-408.

Cheung, Yin-Wong, Menzie D. Chinn and Eiji Fujii (2003), "The Chinese Economies in Global Context: The Integration Process and its Determinants," NBER Working Paper no. 10047 (October).

Cote, Agathe (1994), "Exchange Rate Volatility and Trade: A Survey,” Bank of Canada Working Paper no. 94-5.

Eichengreen, Barry (1996), Globalizing Capital: A History of the International Monetary System, Princeton: Princeton University Press.

Eichengreen, Barry (2002), "International Monetary Options for the $21^{\text {st }}$ Century," Annals of the American Academy of Political and Social Science 579, pp.11-25.

Eichengreen, Barry and Paul Masson et al. (1998), "Exit Strategies: Policy Options for Countries Seeking Greater Exchange Rate Flexibility," IMF Occasional Paper no. 168.

Garber, Peter (2003), “Comments," IMF Economic Forum on Capital Flow Cycles, www.imf.org, 18 November.

Goldstein, Morris (2003), “China’s Exchange Rate Regime,” Testimony before the Subcommittee on Domestic and International Monetary Policy, Trade and Technology, Committee on Financial Services, U.S. House of Representatives, Washington, D.C. 1 October, www.iie.com.

Goldstein, Morris and Nicholas (2003), “Two-Stage Currency Reform for China,” The Asian Wall Street Journal (12 September).

Ianchovichina, Elena, Sethaput Suthiwart-Narueput and Min Zhao (2003), "Regional Impact of 
China's WTO Accession," unpublished manuscript, World Bank.

Ianchovichina, Elena and Terrie Walmsley (2003), "Impact of China's WTO Accession on East Asia," unpublished manuscript, the World Bank.

Ihrig, Jane and David Prior (2003), "The Effect of Exchange Rate Fluctuations on Multinationals' Returns," International Finance Discussion Paper no. 782, Washington, D.C.: Board of Governors of the Federal Reserve System (October).

International Monetary Fund (2003), "IMF Concludes 2003 Article IV Consultation with People's Republic of China," www.imf.org, 18 November.

Jorian, Philippe (1990), "The Exchange Rate Exposure of U.S. Multinationals," Journal of Business 63, pp.331-345.

Kanno, Masaaki (2003), “Japanese Exports Supported by China's Capex Drive,” J.P. Morgan Global Data Watch, 21 November, pp.13-14.

Kuroda, Haruhiko (2003), "How to Help the Renminbi Find its Own Level," Financial Times, 17 October, p.15.

Kynge, James and David Pilling (2004), "China's Growth Helping to Soak Up Excess Japanese Capacity,” Financial Times (12 January), p.10.

Lardy, Nicholas (1992), Foreign Trade and Economic Reform in China 1978-1990, Cambridge: Cambridge University Press.

Lardy, Nicholas (2002), Integrating China into the Global Economy, Washington, D.C.: Brookings Institution.

Malcolm, James and Yen Ping Ho (2004), “China’s Two-Step Reval: Bask Peg Soon, Bigger Move Later," J.P. Morgan Asian Rates Research (16 January), pp.1-3.

McKibbin, Warwick and Andrew Stoeckel (2003), "What if China Revalues its Currency?" Economic Scenarios 7 (December).

Merrill Lynch (2004), "China's FX Regime: Moving the Great Wall,” Global Foreign Exchange Strategy Department, New York: Merrill Lynch (March).

Mundell, Robert (2003), "Renminbi Valuation and Eastern Asia Currency Stability," unpublished manuscript, Columbia University, September.

$\mathrm{Ng}$, Grace (2005), "China: Rising BoP Surplus is Complicating Monetary Policy," J.P. Morgan Global Data Watch (4 February), pp.13-16.

Obstfeld, Maurice and Kenneth Rogoff (2004), “The Unsustainable U.S. Current Account 
Position Revisited," NBER Working Paper no.10869 (November).

Ong, Sin Beng (2004), “Foreign Inflatows and Challenges," J.P. Morgan Global Data Watch (28 February), p.69.

Ouyang, Alice Y and Ramkishen S. Rajan (2005), "The Extent and Effectiveness of Monetary Sterilization in China Since the 1990s," unpublished manuscript, National University of Singapore.

Rose, Andrew K. (2000), "One Money, One Market: Estimating the Effect of Common Currencies on Trade," Economic Policy 15, pp.7-46.

Shafaeddin, S.M. (2003), "The Impact of China's Accession to WTO on the Exports of Developing Countries," UNCTAD Discussion Paper no. 160 (June).

Taylor, John B. (2003), "China's Exchange Rate Regime and its Effects on the U.S. Economy," Testimony before the Subcommittee on Domestic and International Monetary Policy, Trade, and Technology, House Committee on Financial Services, 1 October.

Ward, Andrew and Barney Jopson (2003), "Seoul Urges China to Ease Currency Peg," Financial Times, 23 July, p.1.

Williamson, John (2003), "The Renminbi Exchange Rate and the Global Monetary System," Lecture delivered at the Central University of Finance and Economics, Beijing, 29 October, www.iie.com.

Yang, Tongzheng and David Vines (2000), "The Fallacy of Composition and the Terms of Trade of Newly Industrializing Economies," unpublished manuscript, Oxford University.

Zheng, Joan (2003a), "China: Domestic Reverberations of the Renminbi Peg," J. P. Morgan Global Data Watch, 19 September pp.11-13.

Zheng, Joan (2003b), "China's Export Surge Reflects Structural Trends," J.P. Morgan Global Data Watch, 13 June, pp.19-20. 


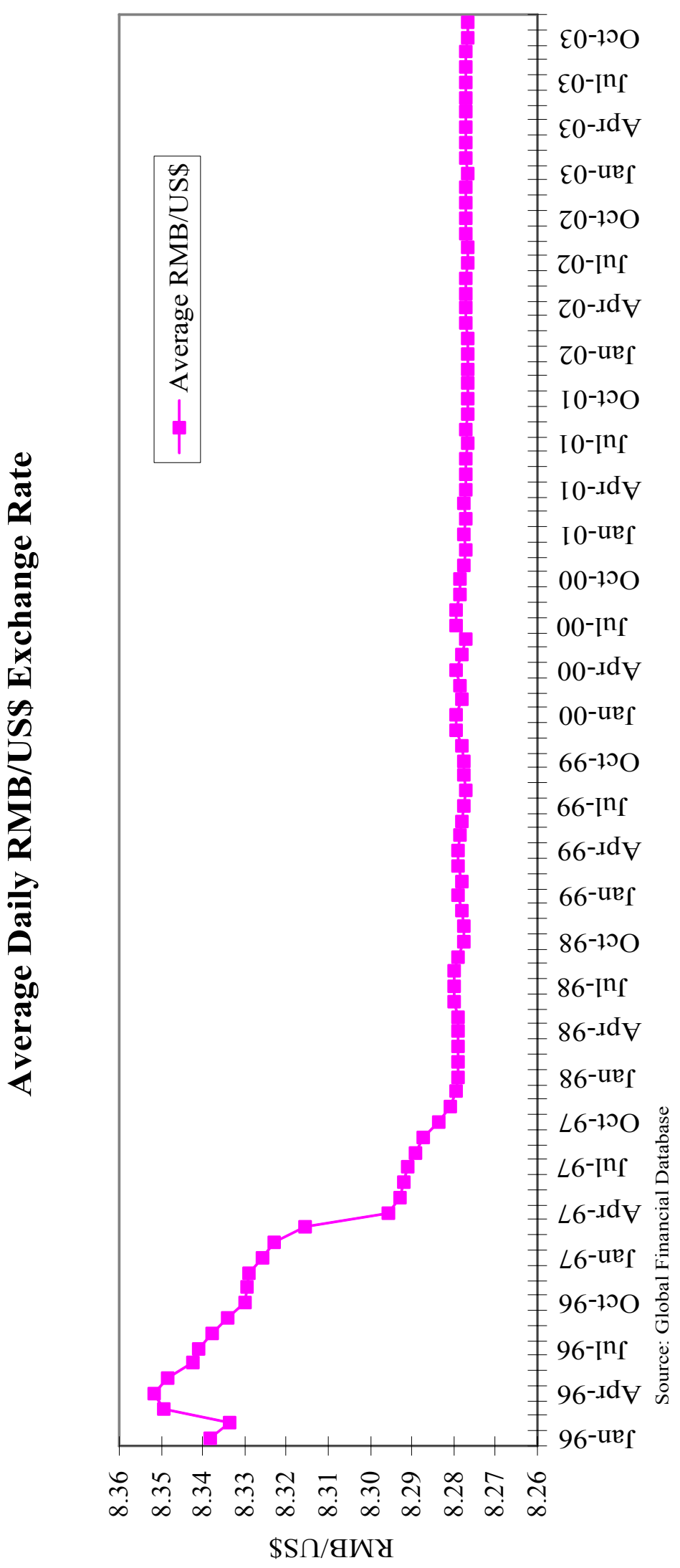




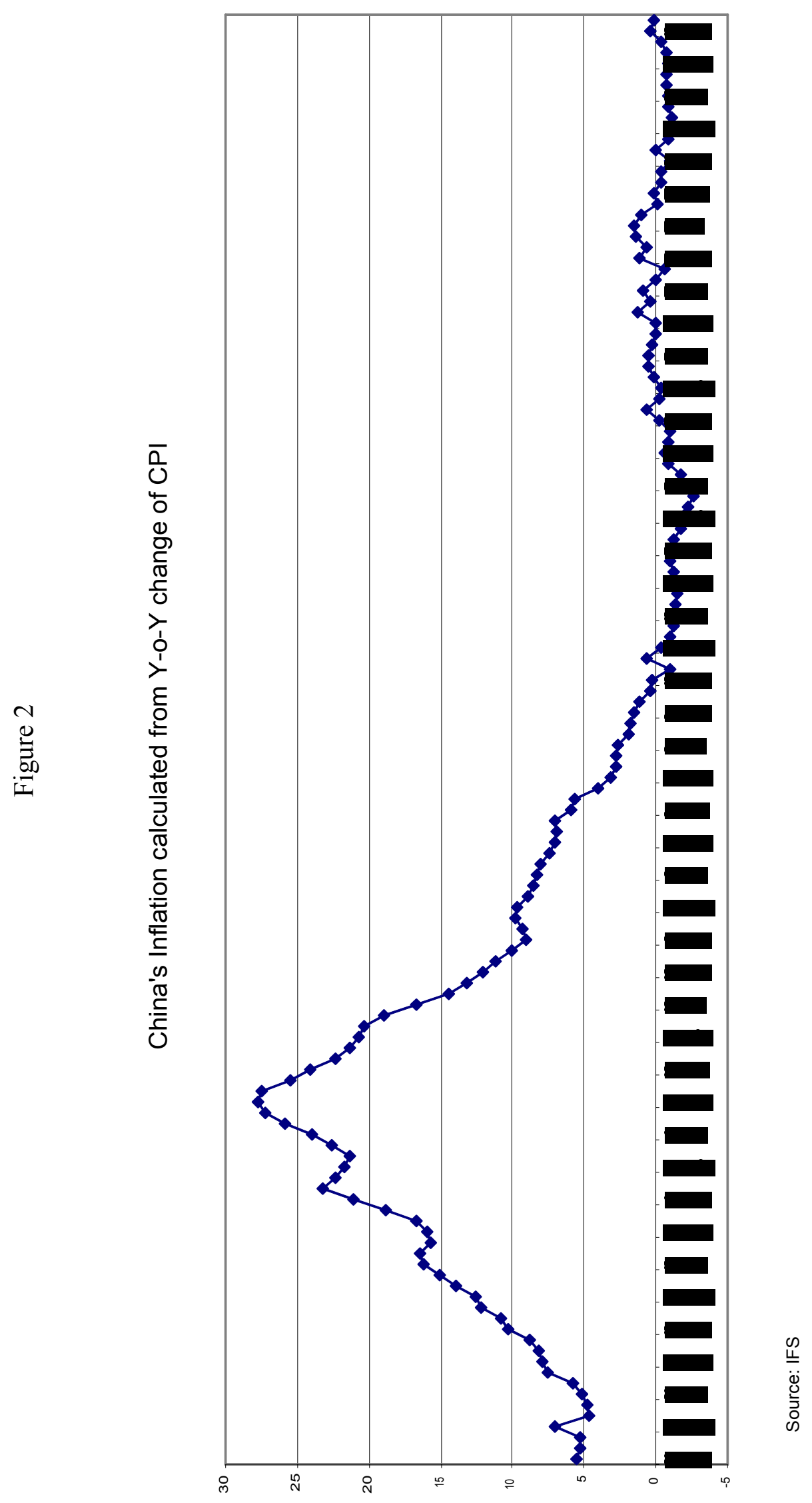




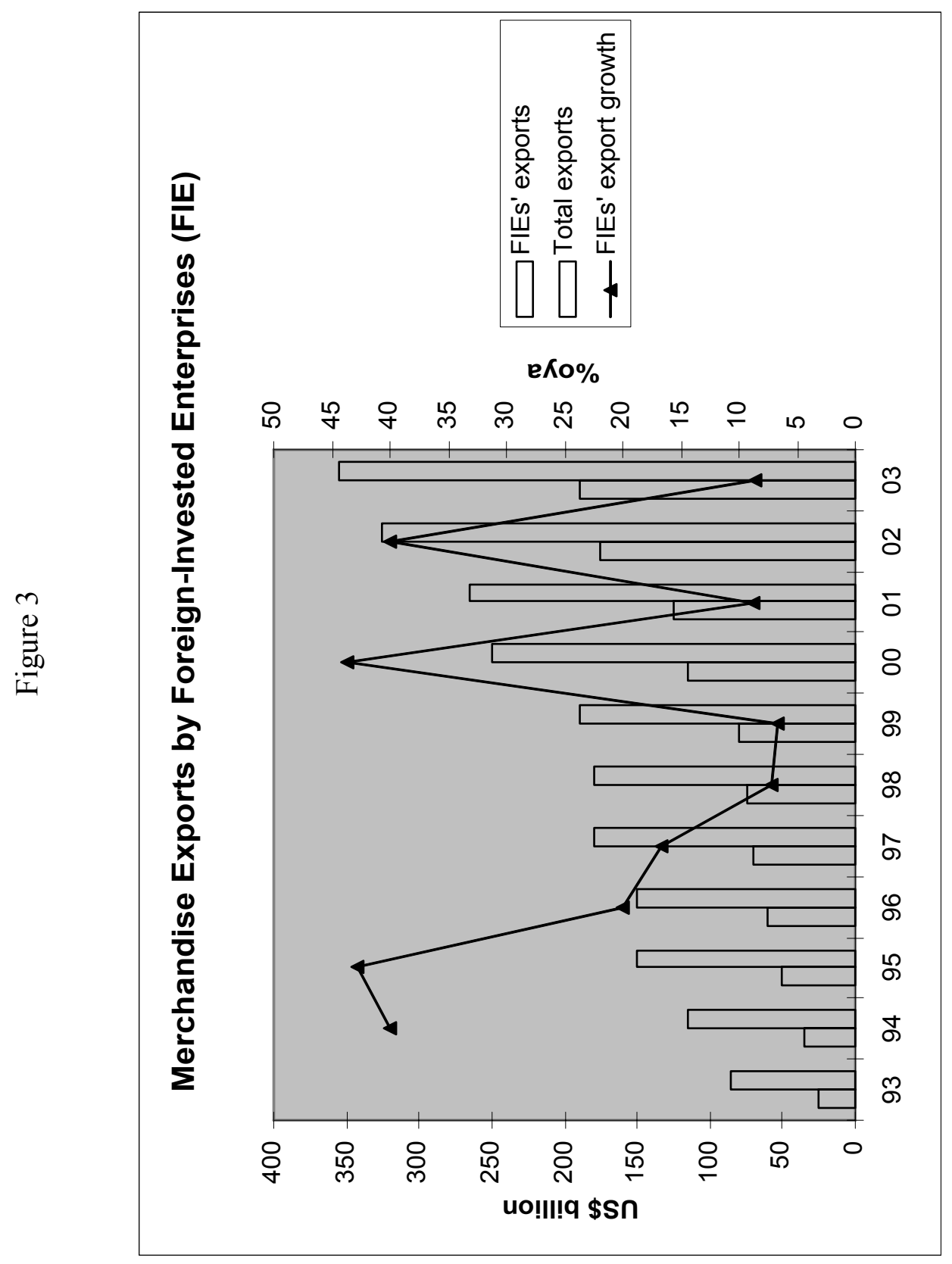




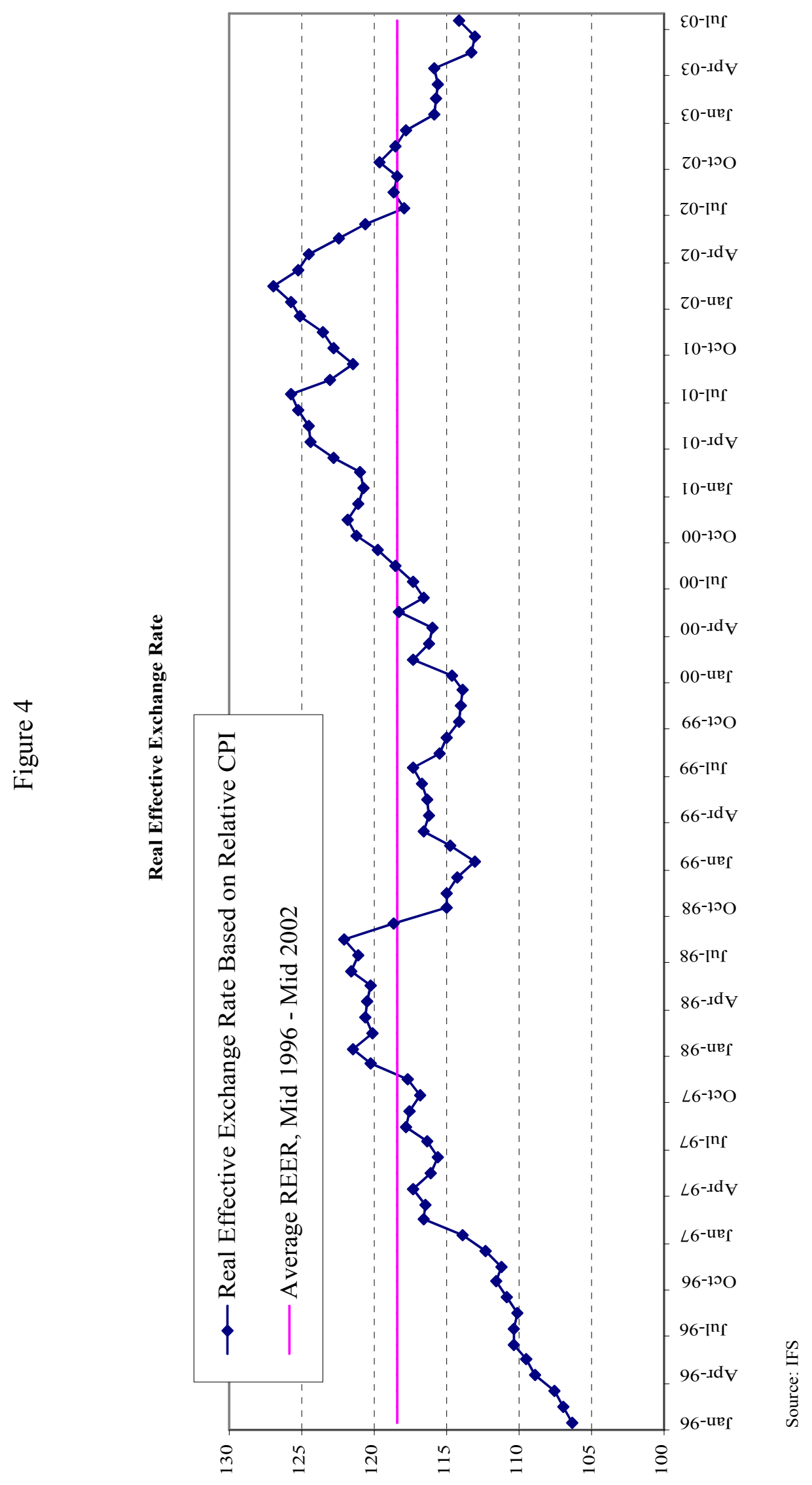




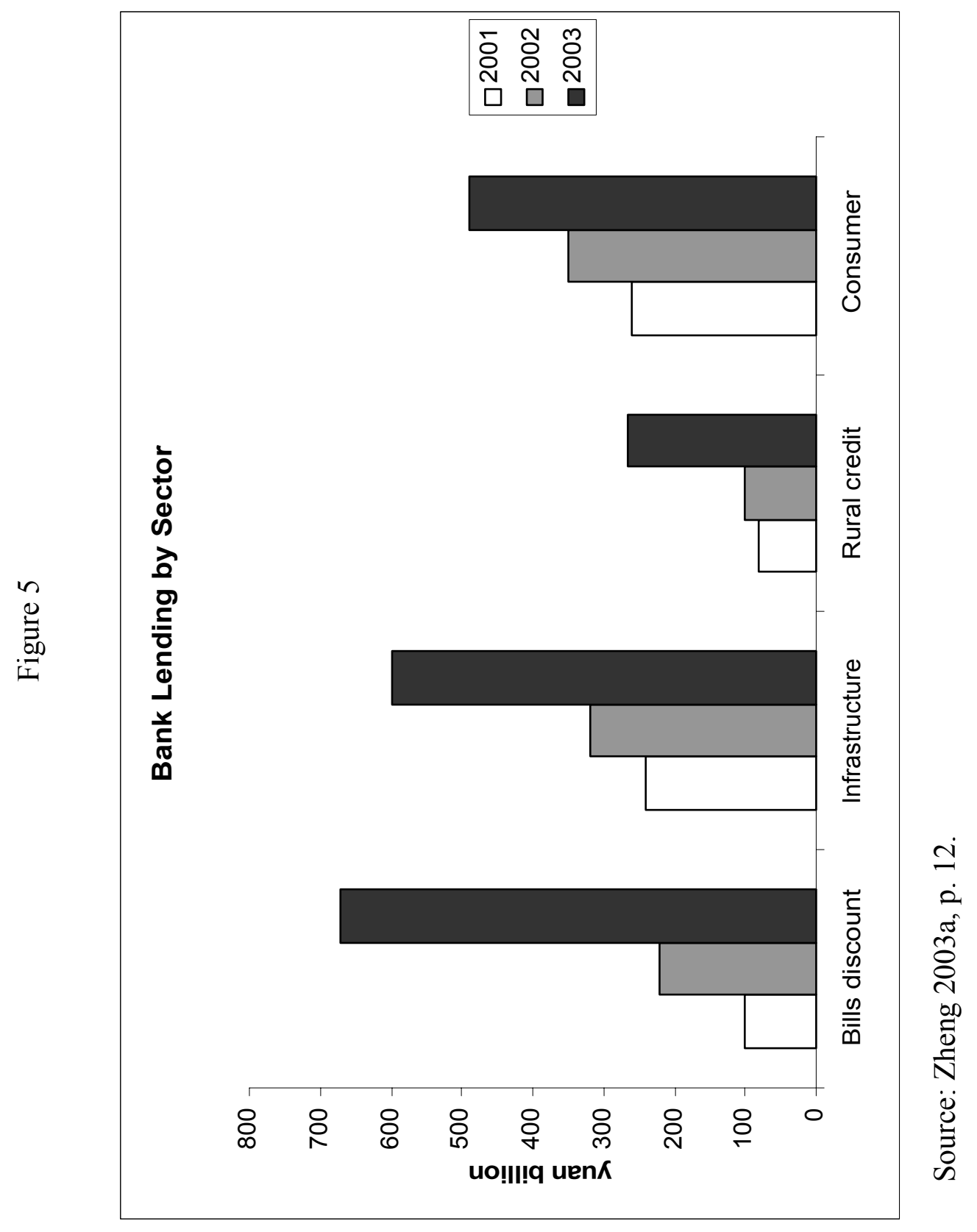




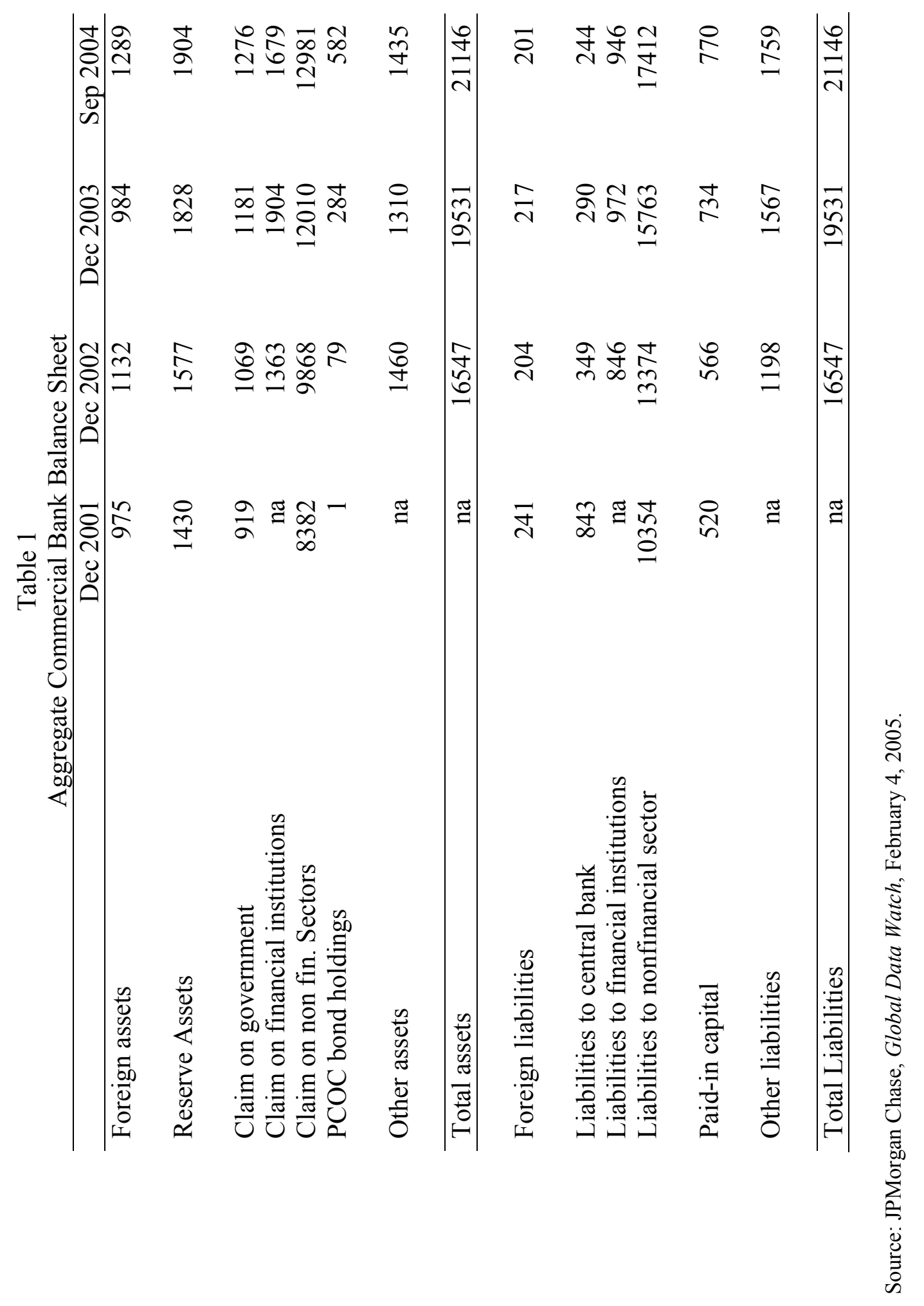

